\title{
Review of the Political Direction of National Legal Development Law ${ }^{*}$
}

\author{
Achmad Irwan Hamzani ${ }^{1 *}$, Kanti Rahayu' ${ }^{2}$, Toni Haryadi ${ }^{3}$, \\ Nur Khasanah ${ }^{4}$, Havis Aravik ${ }^{5}$ \\ 1-3Universitas Pancasakti Tegal, ${ }^{4}$ IAIN Pekalongan, 5STEBIS IGM Palembang \\ 10.15408/jch.v9i2.20352
}

\begin{abstract}
The political direction of the law in Indonesia in the development of national law simplifies legislation. The scope of national legal development is not only through legislation. There is the functionalization of the law that lives in society. The purpose of the research describes the political urgency of law in the development of national law and reviews the political direction of national law development law. This research uses a philosophical approach, namely to examine the law from the ideal side in the form of an idea of the direction of national law politics in the future. The results of this study show that the politics of law is necessary to provide direction in the development of national law. Each country has a legal political direction whose role as the basic policy of state organizers to determine the direction, shape, and content of the law to be established. Legal politics as a strategy of the formation process, as well as the implementation of laws based on the national legal system to achieve the goals and ideals of the state. The political direction of the law in Indonesia in the development of national law simplifies legislation.
\end{abstract}

Keywords: The Political Direction of Law; The Development of National Law; The Living Law

*Received: April 12, 2021, revised: May 18, 2021, accepted: June 17, 2021, Published: 31 August, 2021.

${ }^{1}$ Lecturer in Law Faculty of Pancasakti University, Tegal, Central Java, Indonesia.

${ }^{2}$ Lecturer in Law Faculty of Pancasakti University, Tegal, Central Java, Indonesia.

${ }^{3}$ Lecturer in Law Faculty of Pancasakti University, Tegal, Central Java, Indonesia.

${ }^{4}$ Lecturer of IAIN Pekalongan, Central Java, Indonesia.

5Lecturer of STEBIS IGM Pelembang, South Sumatera, Indonesia.

*Corresponding author: al hamzani@upstegal.ac.id 


\title{
Tinjauan Arah Politik Undang-Undang Pembangunan Hukum Nasional
}

\begin{abstract}
Abstrak
Arah politik hukum di Indonesia dalam pembangunan hukum nasional menyederhanakan pada legislasi. Cakupan pembangunan hukum nasional sebenarnya tidak hanya melalui legislasi. Ada fungsionalisasi hukum yang hidup di masyarakat. Tujuan penelitian mendeskripsikan urgensi politik hukum dalam pembangunan hukum nasional, dan mereview arah politik hukum hukum pembangunan hukum nasional. Penelitian ini menggunakan pendekatan filosofis, yaitu mengkaji hukum dari sisi ideal berupa gagasan arah politk hukum nasional ke depan. Hasil penelitian ini menunjukan bahwa politik hukum sangat diperlukan guna memberikan arah dalam pembangunan hukum nasional. Setiap negara memiliki arah politik hukum yang perannya sebagai kebijakan dasar penyelenggara negara untuk menentukan arah, bentuk maupun isi hukum yang akan dibentuk. Politik hukum sebagai strategi proses pembentukan, serta pelaksanaan hukum yang berpijak pada sistem hukum nasional untuk mencapai tujuan dan cita-cita negara. Arah politik hukum di Indonesia dalam pembangunan hukum nasional menyederhanakan pada legislasi.
\end{abstract}

Kata Kunci: Arah Politik Hukum; Pembangunan Hukum Nasional; The Living Law

\section{Обзор политической направленности национального закона о правовом развитии}

\begin{abstract}
Аннотация:
Направление правовой политики Индонезии в развитии национального права упрощено до законодательного. На самом деле, развитие национального права осуществляется не только через законодательство. Существует действующий закон, который живет в обществе. Цель исследования - описать актуальность правовой политики в развитии национального права и рассмотреть направление правовой политики в развитии национального права. В данном исследовании используется философский подход, который рассматривает право с идеальной стороны в виде идей политического направления национального права в будущем. Результаты этого исследования показывают, что правовая политика необходима для определения направления развития национального права. В каждой стране существует правовое политическое направление, роль которого заключается в том, чтобы руководствоваться государственной администрацией в качестве основной политики по определению направления, формы и содержания закона, который должен быть сформирован. Правовая политика как стратегия процесса формирования и реализации закона основана на национальной правовой системе для достижения целей и идеалов государства. Направление правовой политики Индонезии в развитии национального права упрощено до законодательного.

Ключевые Слова: Направление Правовой Политики; Развитие Национального Права; Живое Право
\end{abstract}




\section{A. INTRODUCTION}

The political direction of the law in Indonesia in the development of the law simplifies its scope on the list of legal material plans to be made. The development of criminal law means to make a Draft Law of the Criminal Law which will then be discussed and ratified by the House of Representatives (DPR). The plan for the development of legal materials is contained in the National Legislation Program (PROLEGNAS), and for the Regional level can be seen through the Regional Legislation Program (PROLEGDA). PROLEGNAS were prepared by the DPR together with the Government coordinated by the DPR based on the direction and priority to be used as a short-term program and scheduled discussions in the House of Representatives. Determination of the direction and priority of Prolegnas is addressed between the Government and the House of Representatives.

Several important points serve as the direction and priority of national legal development, among others are "establishing legislation in the field of law, economics, politics, religion, education, science and technology, socio-cultural, regional development, natural resources, and the environment, land, and security as the implementation of the mandate of the1945 Constitution". Furthermore, "replacing the colonial heritage legislation and perfecting existing laws and regulations that are no longer following the development of the times". Because all the products of colonial heritage legislation are considered incompatible with the nation's culture, so it is necessary to create a law imbued with Indonesian legal culture (Arifin, 2017).

If the law is defined as a "tool" to achieve goals and achieve the goals of the nation and the country, then the politics of law is the direction that must be taken in the manufacture and enforcement of the law. The politics of law is an attempt to make the law a process of achieving ideals and objectives, and guiding how to make the law right according to the constitution and keep it through the politics of law (Mahfud M.D., 2007).

The law is closely related to social changes. The law is a reflection of social solidarity in society. The law needs to be seen as a community institution that serves to meet social needs. So in the context, the development of national law must be able to achieve the material welfare and spiritual of society and individuals (as welvaartstaat). The formulated law is also not just a collection of dead letters. The effectiveness of the law does not stand alone but is closely related to societal issues, especially the issue of public legal awareness of the values that have been embraced. The development of national law cannot be separated from the development of Indonesian society. 
Effective and successful or not legal, depending on three elements of the legal system, namely the legal structure, substance/material law, and legal culture (Friedman, 2011). Legal development is certainly not quite focused on the development of several laws. As a political action, the development of the law will depend at least on the seriousness of the structure/implementation of the law. It is they who are in control of determining the direction, as well as the pattern and material.

The problem that will be examined in this research is the political urgency of the law in the development of the current national law. Further reviewing the political direction in the development of national law.

\section{B. METHODS}

This type of research is library research. Literature research is research that is carried out by researching library materials or secondary data (Hadi, 2010). This research includes literature research because the data used is secondary data in the form of legal documents. Furthermore, secondary data are grouped into primary legal materials and secondary legal materials. Primary legal material is a binding legal material as contained in the hierarchy legislation. While secondary legal materials are legal materials that explain primary legal materials such as draft laws, research results, and scientific work of legal experts (Ali, 2019). This study uses primary legal material because it makes some related legislation as a reference. While using secondary legal materials because it makes some books, journals, and other writings as a reference. The approach used in this study is philosophical. The philosophical approach in legal research is to examine the law from the ideal side. This research uses a philosophical approach because it formulates a law that is still at the desired level (ius constituendum), in the form of an idea of the direction of national law politics in the future. The data source used by this study is secondary data. Secondary data is data obtained indirectly or has been provided by other parties. Secondary data used in the form of legal documents that serve as the main reference to review the political direction of the law in the development of national law. Data collection techniques were used in this study through offline and online research. Offline library expansion is the activity of finding library resources to where data is stored. While online approval is the activity of finding library resources in cyberspace through the internet network. Library expansion is conventionally done by finding library materials to libraries, collections of books and personal journals, purchasing books, and visiting scientific activities (seminars). While online expansion is done by searching on the internet. The method of data 
analysis used is qualitative. Qualitative data analysis is the process of organizing and sorting data into patterns, categories, and units of basic description so that it can be found themes presented in the form of narratives. This study uses qualitative data analysis because the data will be presented in a narrativedescriptive manner, not in the form of numbers or numerical.

\section{RESULTS AND DISCUSSION}

\section{The Political Urgency of Law in the Development of National Law}

The politics of law are indispensable to provide direction in the development of national law. Each country has a legal political direction whose role as the basic policy of state organizers to determine the direction, form, and content of the law to be established (Frenki, 2011). Etymologically, legal politics comes from the Dutch term Rechtspolitiek. A term is a form of the words rechts and politiek. Legal politics in Indonesian rechts means law, and politiek means beleid or policy. Politics or policy is a set of concepts and principles that become the outline and basis of the plan in the implementation of a job, leadership, and way of action (Rahayu, 2015). Based on this explanation, the politics of the law can briefly be interpreted as legal policy.

Simply put, the politics of law can be formulated as a legal policy that will or has been implemented nationally by the government. It also includes an understanding of how politics affects the law by looking at the configuration of the forces behind the creation and enforcement of it (Artina, 2010). The politics of law is the government's policy on which laws will be retained, which laws will be replaced, which laws will be revised, and which laws will be eliminated. Through the politics of state law, a draft and plan for the development of national law in Indonesia. The achievement of legal development will encourage the achievement of legal goals that further lead to the creation of state goals (Fitriana, 2015). The politics of law are very related to ideals and expectations, so there must be a vision of the law. The vision of the law can be formatted form and content of the law that is considered capable to realize the purpose of the law as a continuation of the purpose of the state.

Legal politics is a voting activity and a way to be used to achieve a certain social and legal goal in society. Several fundamental questions arise in the study of legal politics, namely: (1) what objectives to achieve with the existing legal system; (2) what ways and which, it feels best to be used to achieve that goal; (3) when the time of the law needs to be changed and by how it should be made; and 
(4) can a standard and established pattern be formulated, which can help decide the process of choosing goals and ways to achieve those goals well.

Legal politics according to Mahfud MD., (2009) is a legal policy or official line on the law that will be enforced both with the new law and with the replacement of the old law, to achieve the goals of the state. There are 3 (three) legal political groups, namely: First, the official direction of the law to be enforced (legal policy) to achieve the state objectives that include the replacement of the old law and the establishment of new laws altogether. Second, the political background and other societal sub-systems behind the birth of the law, including the official direction of the law that will or will not be enforced. Third, the issues surrounding law enforcement, especially the implementation of the politics of the law that has been outlined. The basis of legal politics is to realize the objectives of the state and the legal system of the country concerned in the context of Indonesia, the purpose and legal system contained in the Preamble to the 1945 Constitution, especially Pancasila which gave birth to the methods of legal guidance.

Thus the politics of law is the policy of building the national legal system (Sutrisno, 2016). The politics of the law contain several provisions, among others: First, Legal Dogmatics that explains the content of the law, the meaning of the provisions of the law, and arrange it under the principles in a legal system. Second, the History of Law studied the old legal structure that had an influence and role on the formation of the current law. The history of the Law has significance when we want to gain a good understanding of the current law. Third, is the Science of Comparative Law is to conduct legal comparisons that occur in various countries, examine similarities, and differences. Fourth, The Politics of Law, is tasked to explore which changes need to be made to the existing law to meet new needs in people's lives. Fifth, General Law explains not studying a particular rule of law, but sees it as a thing in itself, apart from the specificity associated with time and place. General Law seeks to determine the basis of understanding of the law, legal obligations, persons or persons capable of acting in law, legal objects, and legal relationships. Without this basic understanding, there could be no law and law (Erika, 2014).

There are 3 (three) models of the relationship between law and politics. First, the law of determinants over politics. The reality of such a relationship is based on the assumptions and views of das sollen, what it should be. Second, the politics of determinants of the law, which is based on the view of using das sein, what and how it is in fact. Third, based on the assumption das sollen-sein legal and political relations cannot be said there is more dominant or superior because 
the two symmetrically affect each other. If for example politics is interpreted as power, then the statement "politics and law is determinant" because lawless politics is wrong while law without politics is paralyzed (Rahayu, 2015).

The politics of law seek to create rules that will determine how people should act. The politics of law investigate what changes must be made in the current law to become following the existing social werkelijkheid, however, sometimes also to keep the legal system away from social reality, namely when the law becomes a tool of ruling class groups who want to realize their political goals regardless of existing social reality (Djatmiko, 2018). The political position of the law is very important in producing various legal products that will be used in realizing the ideals and objectives of the law.

In the event of political obscurity of the law will result in the rule of law in the form of a cross-party law, and it is not clear the stage of implementation. That confusion will then get people used to doing 'by-passes at all stages of government. The habit of cutting the compass at a later stage will encourage people to speculate on the law by holding on to adigium: "if it is not clear the law, then it may be the rule". Widespread legal speculation will send the public to the next level, namely the situation without legal certainty. At this stage, of course, it will result in the law will not reach the essential purpose of the law and greatly harm the community and the state as a major part of the law.

The politics of law are present at the point of encounter between the realism of life and the demands of idealism. The politics of law speak of 'what it should be', which is not always synonymous with 'what is. Legal politics is not passive towards 'what is, but rather actively seeking what it should be' (Maryanto, 2012). The political balance of the law will be seen when reflected in the products of law, the development of the law, as a broader social dynamic or political equilibrium, and the principle of check and balance democracy (Sarip, 2018).

The politics of national law as the content of the direction of the development of the national legal system (Chotijah, 2015). The politics of national law has established Indonesia as a country based on law (rechtsstaat), as stipulated in Article 1 paragraph (3) of the 1945 Constitution. The concept of the state law refers to the soul of the nation (volkgeist) contained in Pancasila and the Proclamation of Independence as the source of all legal sources and the buffer of conventionalism (Marbun, 2014). The politics of national law is a tool and means used by the government to establish a national legal system. One of the political directions of national law proclaimed by Indonesia after the agenda of constitutional reform is to continue the agenda of formation and change of law 
(legal reform). Moreover, the existence of legal globalization is necessary for the development of law in an integrated and sustainable manner following the national legal order based on the values contained in Pancasila and the 1945 Constitution (Waluyo et al., 2019).

\section{Review of the Political Direction of National Law Development Law}

National legal development is a series of sustainable legal development efforts covering various aspects of people's lives, national and state, to realize the national goals formulated in the Preamble to the 1945 Constitution (Ardhanariswari \& Fauzan, 2018). The development of national law based on the politics of law is a very long work, even a lifetime with the development of the state (Waluyo et al., 2019).

The scope of the development of the national legal system can be through legislation and functionalization of the living law (the law that lives in the community). Because no law stands alone and does not appear by chance, but is born from the inner consciousness of society, therefore the law develops along with the development of its people, including the law in Indonesia (Ahmad, 2020). Therefore, the political direction of the law in Indonesia in the development of national law simplifies the process of legislation. The impact will only be a successful legal state in law-making, but weak in law in action. Therefore, the government should consider the political direction of the law through the functionalization of the living law. By functionalizing "the living law" can minimize resistance in the community because it raises the values that have shaped the legal awareness of the community. Clashes with Indigenous peoples that often appear are expected to also be minimized. For example, when dealing with the interests of investors who are legitimized positive law.

The living law is important to be empowered in the development of the national legal system. National law will be a law that comes from the reality of people's lives. The authority that determines the enforceability of the law should not only be through the power of the state, but also by the legal awareness of the community. The living law also determines the enforceability of the law in the community. The living law is a set of provisions that are born along with the birth of society. The law cannot be removed from society. The law serves the interests of the community. Supposedly the law made by the government (state law) is also dependent on the factors of society.

Society is a fabric of rules. Each society produces its type and type of law and creates legal traditions according to its own culture. There are traditions of 
civil law and common law that have different characteristics because they develop and grow in different cultural lives.

The politics of national law should always be directed at the following: First, the consistent implementation of existing legal provisions. Second, the construction of a law that is essentially done for the renewal of existing legal provisions and considered obsolete, and the creation of new legal provisions necessary to meet the demands of developments that occur in society. Third, affirmation of the function of law enforcement agencies or the implementation of law and coaching of its members. Fourth, increase public legal awareness according to the perception of elite group policymakers (Latif \& Ali, 2011).

According to the constitutive basis, in terms of efforts to realize the Politics of National Law, the Indonesian nation has 5 (five) frameworks or benchmarks that are targeted and to be achieved, including: (1) Policy, in the sense of the basic policy of state administration, (2) Basic policymaking, (3) What legal substance/material is made to achieve national goals, (4) Legal processes that include the order of legislation containing Legal Politics such as TAP. MPRS No. XX Year 1966, TAP. MPR No. 5 of 1973, TAP. MPR No. IX Year 1978, TAP. MPR No. III Year 2000 and Law Number 10 the Year 2004, (5) Establishment of National Law by relying on the regulatory basis, namely how the legislation is formulated by the context of rechtsidee. These five points are the goal to achieve the development of a national legal system in which the national legal system itself is the basis of the Indonesian National Legal Politics (Erika, 2014).

The above five benchmarks are derived from the legal classification according to the view of national legal development because the new law consists of 5 (five) classifications of the law. The basic policy is often called legal politics, basic policy-making based on customary law, religious law, western law, and national law. Overall, it remains based on the values of Pancasila and the 1945 Constitution. The substance of the law cannot escape the five laws and has been established through a process that leads to the establishment of a sustainable national law. And must be in line with the order of the values of life in the state, both basic values, instrumental values, and praxis values all of which are contained in Pancasila and the 1945 Constitution (Erika, 2014). Which will be tangible on the operational basis, namely: 1) a just and prosperous law; 2) the law of strengthening democracy; 3) human rights protection law; 4) unity in diversity-based law (Bhinneka Tunggal Ika); and 5) laws that protect the nation and state of Indonesia (Riyanto, 2020).

The basic interests of the citizens can be fulfilled. The development of national law must be able to achieve the material welfare and spiritual of society 
and individuals (basic welvaartstaat) and the formulated law is not just a collection of dead letters. The effectiveness of the law is not a stand-alone issue, but rather closely related to other societal problems, especially problems, the development of the character of the Indonesian nation. The development of national law cannot be separated from the development of Indonesian society.

If the law is interpreted as a "tool" to achieve the ideals and achieve the goals of the nation and the state, then the politics of law is the direction that must be taken in the manufacture and enforcement of the law to achieve the ideals and objectives of the nation and state. The politics of law is an effort to make the law a process of achieving goals and objectives, and guiding how to make the law right according to the constitution, and keeping it through the politics of law (Mahfud MD., 2009).

Throughout the history of legal politics in Indonesia, there has been a frequent tug-of-war between democratic political configuration and authoritarian configuration. Democracy and authoritarianism appear linearly with their nature or with goals to be achieved. The law is used only for the benefit and support of the political objectives of the government. The position of the government is very dominant with the interventionist nature in the determination and implementation of state policies so that the potential and aspirations of the community are not aggregated and articulated proportionally. Law as a complex arrangement has been reduced to something simple, linear, mechanistic, and deterministic, especially for the benefit of the profession, and is still dominant in Indonesia (Rahardjo, 2009). The logic of the law is still in the realm of law is the decision of the authorized bodies, beyond that it is not considered legal. The law turned into an esoteric world, having its own "grammar" (private language) that is difficult to understand by the extra-legal world (Ridwan \& Dimyati, 2016).

The role of the government is very dominant, the representative body of the people and political parties do not function properly and is more a tool for justification (rubber stamp) on the will of the government, while the press does not have freedom and is always under the control of the government in the shadow of banter (Wibawa, 2016). The government becomes "the king can do no wrong" where on behalf of the state the government cannot be touched by the positive laws of the state. Unfortunately, it lacks the space for citizens to build a just country. Legal products formed by the legislature, judiciary, and executive, produce only welfare, order, and justice for a handful of people and the resistance of society to the product of the law becomes very strong (Sarip, 2018). 
On the contrary, in a democratic system of regimes, the law is diametrically separate from politics, meaning that the law is not a subordination of politics. Lawmaking involves the participation of the people, the content is aspirational to the needs of the community and the details of its contents are limitative, so as not to cause confusing multi-interpretation and result in the absence of legal certainty. This means that there is room for community participation to be fully involved in determining state policy. Public participation is determined on the principle of a majority by representatives of the people in periodic elections based on the principle of political equality and held in an atmosphere of political depravedness in a democratic country. As a result, a responsive legal product was formed. The ruler is more of an organization that must carry out the will of its people, which is formulated democratically (Wibawa, 2016). This position in the law becomes a reference in politics for the government in managing the country and its people, but in the generality, the political sub-system has greater energy so that the law is always in a weak position. That is why empirically, politics is very decisive in the pattern and working of the law (Djatmiko, 2018).

The law is a political product resulting from the compromise of political elites. Political elites should pay attention to social factors as a social reality. Legal products formulated democratically, of course in the process of drafting it always see the will and aspirations that grow in the community, so that the legal products that will be produced are following the conscience of the community. If the resulting legal product turns out to make the community restless, against, and inclined to disobey the provisions of the law (civil disobedient) indicates that the legal product is 'defective' and unable to make a real contribution to the achievement of harmony, peace, order and social benefit (Djatmiko, 2018).

It is necessary to observe the reality that the implementation of legal development in the country of Indonesia, basically inseparable from the development of legal aspects dug from the fundamental values of the nation's culture and known as the noble values of Pancasila law. As the ideology and philosophy of the Pancasila nation should not contain values that are contrary to his values, including in the practice of law carried out (Shofiana, 2014). Pancasila in its capacity as a constitutive basis inspires that the implementation of the state regulation of the Republic of Indonesia that protects the life of society, nation, and state constitutionally must be based on Pancasila.

Building the civility of a nation with Indonesian character is a condition zine qua non for the Nation of Indonesia. This can be realized if individuals of Indonesian people as the main inhabitants of Indonesian civilization have a noble 
national character to build the civility of the nation. The character of the nation in question is the one that has shaped the personality of Pancasila as recognized that Pancasila is the soul and personality of the Indonesian nation (Jagad, Suhendar, \&Rosyid, 2015).

The political face of law in Indonesia to date remains the system of the new order regime even though the democratic system has changed but the change lies only in the structure but in the implementation in the field can still be seen from the legal products made terms with interests and laws in Indonesia more determinant of the authoritarian political configuration so that the legal products produced are more conservative. Various issues of disillusionment with law enforcement and disappointment in the rule of law are largely due to the situation of shifting understanding of the law and the process of law formation and undemocratic legal rulings (Salam, 2015).

Thus, the political direction of the law in Indonesia to accelerate the realization of the national legal system needs to be edged by expanding the scope of legal development that does not concentrate on legislation programs. Functionalization of the living law can be considered. The living law has formed a public legal awareness so that by functionalization will be obtained the law that bottoms up the minimal potential resistance.

\section{CONCLUSIONS}

Based on the above discussion, it can be concluded that legal politics is needed to provide direction in the development of national law. Every country has a legal political direction which serves as the basic policy of state organizers to determine the direction, shape, and content of the law to be established. In the event of political obscurity, the law will result in the rule of law in the form of unclear laws. Legal politics includes the process of law-making plans, implementation, to future legal plans. Legal politics as a strategy of the formation process, as well as the implementation of laws based on the national legal system to achieve the goals and ideals of the state. Ideally, the politics of law are based on the ideals of the law, and the legal agenda to realize the goals of the state. The politics of national law is a tool and means used by the government to form a national legal system that can show the identity of the nation. The political direction of the law in Indonesia in the development of national law simplifies on the list of plans of legal materials to be made or make a draft law that will be discussed and ratified by the House of Representatives or legislation. The plan for the development of legal materials is contained in PROLEGNAS, and for the 
regional level of PROLEGDA. This PROLEGNAS was prepared by the DPR together with the Government coordinated by the DPR. PROLEGNAS are prepared based on direction and priority to be used as a short-term program and are scheduled for discussion in the House of Representatives. The scope of the development of the national legal system can be through legislation and functionalization of the living law. Currently, the political direction of the law in Indonesia in the development of national law simplifies the process of legislation. The impact will only be a successful legal state in law-making, but weak in law in action.

\section{REFERENCES:}

\section{Books}

Ali, Z. (2019). Metode Penelitian Hukum. Jakarta: Sinar Grafika.

Friedman, L. . (2011). The Legal System; A Social Science Perspective. Russel Sage Foundation.

Hadi, S. (2010). Metodelogi Research. Yogyakarta: Gadjah Mada Universiti Press.

M. Mahfud MD. (2009). Politik Hukum di Indonesia. Jakarta: Raja Grafindo Persada.

Rahardjo, S. (2009). Pendidikan Hukum sebagai Pendidikan Manusia: Kaitannya dengan Profesi dan Pembangunan Hukum Nasional. Yogyakarta: Genta Publising.

Latif, A. \& H. Ali. (2011). Politik Hukum I. Jakarta: Sinar Grafika.

\section{Journal article}

Arifin, S. (2017). A Roadmap of the Development of Indonesian Law in the Midst of Globalization. International Journal of Business, Economics and Law, 13(4), 55-59. https://www.ijbel.com/wp-content/uploads/2017/09/LAW-89.pdf

Chotijah, G. S. (2015). Reconstructing Indonesian Economic System Based on Legal State Principle of Pancasila. South East Asia Journal of Contemporary Business, Economics and Law, 7(3), 23-29.

Fitriana, M. K. (2015). Peranan Politik Hukum dalam Pembentukan Peraturan Perundang-undang di Indonesia sebagai Sarana Mewujudkan Tujuan Negara. Jurnal Legislasi Indonesia, 12(2), 1-27. https://e- 
jurnal.peraturan.go.id/index.php/jli/article/view/403

Mahfud MD, (2007). Politik Hukum dalam Perda Berbasis Syari'ah. Jurnal Hukum IUS QUIA IUSTUM, 14(1), https://journal.uii.ac.id/IUSTUM/article/view/1058/1795

Wibawa, I. P. S. (2016). Politik Hukum Perlindungan Pengelolaan Lingkungan menuju Ekokrasi Indonesia. Kanun Jurnal Ilmu Hukum, 18(1), 51-68. http://www.jurnal.unsyiah.ac.id/kanun/article/view/5918

\section{Journal article with DOI}

Ahmad. (2020). Legal Politics of Development And Industrial Empowerment Law In Indonesia. Nomoi Law Review, 1(2), 232-244. https://doi.org/https://doi.org/10.30596/nomoi.v1i2.5196

Ardhanariswari, R., \& Fauzan, M. (2018). The Implication of Judicial Review for the National Law Development in Indonesia. 231(Amca), 263-266. https://doi.org/10.2991/amca-18.2018.72

Artina, D. (2010). Politik Hukum Kesetaraan Gender di Indonesia. Jurnal Ilmu Hukum Universitas Riau, 1(1), 65-79. https://doi.org/http://dx.doi.org/10.30652/jih.v1i01.476

Djatmiko, W. P. (2018). Paradigma Pembangunan Hukum Nasional yang Responsif dalam Perspektif Teori J.H. Merryman tentang Strategi Pembangunan Hukum. Arena Hukum, 11(2), 415-432. https://doi.org/DOI https://doi.org/10.21776/ub.arenahukum.2018.01002.10

Erika, D. G. S. M. (2014). Politik Hukum Pancasila dalam Paradigma Nilai-Nilai Sosial Kultural Masyarakat Indonesia. Pandecta, 9(1), 32-49. https://doi.org/DOI: https://doi.org/10.15294/pandecta.v9i1.2856

Frenki. (2011). Politik Hukum dan Perannya dalam Pembangunan Hukum di Indonesia Pasca Reformasi. Asas: Jurnal Hukum Dan Ekonomi, 3(2), 1-8. https://doi.org/https://doi.org/10.24042/asas.v3i2.1662

Dewantara, J.A. \& I.F. Suhendar, R. Rosyid, (2015). Pancasila as Ideology and Characteristics Civic Education in Indonesia. International Journal for Educational and Vocational Studies, 1(5), 400-405. https://doi.org/DOI: https://doi.org/10.29103/ijevs.v1i5.1617

Marbun, R. (2014). Grand Design Politik Hukum Pidana dan Sistem Hukum Pidana Indonesia Berdasarkan Pancasila dan Undang-undang Dasar 
Negara Republik Indonesia 1945. Jurnal Ilmu Hukum, 1(3), 558-577. https://doi.org/DOI: https://doi.org/10.22304/pjih.v1n3.a8

Maryanto. (2012). Politik Hukum Pendidikan. Jurnal Ilmial Civis, 2(1), 199-216. https://doi.org/DOI: https://doi.org/10.26877/civis.v2i1/Januari.597

Rahayu, D. P. (2015). Aktualisasi Pancasila sebagai Landasan Politik Hukum Indonesia. Yustisia, 4(1), 190-202. https://doi.org/DOI: https://doi.org/10.20961/yustisia.v4i1.8634

Ridwan, \& K. Dimyati, (2016). Perkembangan dan Eksistensi Hukum Adat: Dari Sintesis, Transplantasi, Integrasi Hingga Konservasi. Jurisprudence, 6(2), 106-115. https://doi.org/10.23917/jurisprudence.v6i2.3008

Riyanto, B. (2020). National Law Development in New Normal Era. Indonesian Law Journal, 13(2), 87-107. https://doi.org/10.33331/ilj.v13i2.33

Salam, A. (2015). Pengaruh Politik Hukum dalam Pembentukan Hukum di Indonesia. Mazahib, 14(2), 119-131. https://doi.org/DOI: https://doi.org/10.21093/mj.v14i2.341

Sarip. (2018). Pemikiran The King Can Do Not Wrong dalam Politik Ketatanegaraan Indonesia. Kanun: Jurnal Ilmu Hukum, 20(2), 316-336. https://doi.org/DOI: https://doi.org/10.24815/kanun.v20i2.10157

Shofiana, G. F. (2014). Philosophy, Pancasila and Modern Technology. Yuridika, 29(2), 139-148. https://doi.org/http://dx.doi.org/10.20473/ydk.v29i2.363

Sutrisno, B. (2016). Constitutionality Degree of Indonesia Local Regulation in Political Law Perspective. Rechtsidee, 3(1), 41. https://doi.org/10.21070/jihr.v3i1.131

Waluyo, N. F.U., \& Hermawan, S. (2019). Law in the Globalization and Its Influence on Economic Development and Environmental Preservation based on Pancasila and the Indonesian Constitution of 1945. 358(Icglow), 317-321. https://doi.org/10.2991/icglow-19.2019.78 
Achmad Irwan Hamzani, Kanti Rahayu, Toni Haryadi, Nur Khasanah, Havis Aravik

370 - JURNAL CITA HUKUM (Indonesian Law Journal). Vol. 9 Number 2 (2021). P-ISSN: 2356-1440.E-ISSN: 2502-230X 